\title{
Effect of integrated nutrient management on yield and quality of tuberose grown on Vertisol
}

PRITI R. SHIRSAT, OMMALAD. KUCHANWAR, SAGAR N. INGLE, SAINATH ZALTE AND NILESH P. ABGAD

MEMBERS OF RESEARCH FORUM:

Corresponding author : OMMALA D. KUCHANWAR, Department of Soil Science and Agricultural Chemistry, College of Agriculture, NAGPUR (M.S.) INDIA Email: ommalakuchanwar@yahoo.com

Co-authors :

PRITI R. SHIRSAT, SAGAR N. INGLE, SAINATH ZALTE AND NILESH P. ABGAD, Department of Soil Science and Agricultural Chemistry, College of Agriculture, NAGPUR (M.S.) INDIA
Received : 07.03.2015; Revised : 09.10.2015; Accepted : 23.10.2015

\section{Summary}

An investigation entitled effect of integrated nutrient management on yield and quality of tuberose was carried out during Kharif season of the year 2012-13 at the farm of Horticulture Section, College of Agriculture, Nagpur. The treatments comprised of the eleven combinations of organic manures and inorganic fertilizers. The experiment was laid out in Randomized Block Design with three replications. The results obtained in the present investigation indicated that, the flowering parameters, like days required for initiation of first flower stalk, days for 50 per cent flowering and days required for harvesting from initiation of first flower stalk were found minimum in the treatment receiving 50 per cent $\mathrm{N}$ through vermicompost +50 per cent $\mathrm{N}$ through urea $+\mathrm{P}$ and $\mathrm{K}(\mathrm{RDF})$. In respect of yield parameters, the maximum number of spikes per plant, per plot and per hectare were found maximum under the treatment with application of 50 per cent $\mathrm{N}$ through vermicompost +50 per cent $\mathrm{N}$ through urea $+\mathrm{P}$ and $\mathrm{K}$ (RDF). Flower quality parameters, like length of spike, length of rachis, length of floret, diameter of floret, diameter of spike, number of florets per rachis, vase life of cut flowers and oil content were also recorded maximum under the treatment with application of 50 per cent $\mathrm{N}$ through vermicompost +50 per cent $\mathrm{N}$ through urea $+\mathrm{P}$ and $\mathrm{K}(\mathrm{RDF})$. Application of 50 per cent $\mathrm{N}$ through vermicompost +50 per cent $\mathrm{N}$ through urea $+\mathrm{P}$ and $\mathrm{K}$ (RDF) improved the yield and quality of tuberose.

Key words : Integrated nutrient management, Tuberose, Vertisol

How to cite this article : Shirsat, Priti R., Kuchanwar, Ommala D., Ingle, Sagar N., Zalte, Sainath and Abgad, Nilesh P. (2015). Effect of integrated nutrient management on yield and quality of tuberose grown on Vertisol. Asian J. Soil Sci., 10(2) : 210-214. 